\title{
Self-efficacy source and career adaptability: The mediating roles of career decision self-efficacy
}

\author{
Firosyana Rizki Amalia $^{1}$, Farida Kurniawati ${ }^{2}$ \\ ${ }^{1,2}$ Department of Educational Psychology, University of Indonesia, Indonesia \\ ${ }^{1}$ fir.rizki2@gmail.com, ${ }^{2}$ farida1@ui.ac.id
}

ARTICLE INFO

Article history

Received 12 April 2018

Revised 24 January 2019

Accepted 28 February 2019

Keywords

career adaptability, career decision self-efficacy, source of self-efficacy

\begin{abstract}
Career adaptability is defined as individual's ability to make self and environmental assessments in order to deal with changes that occur to themselves and the environment — both planned and unplanned. Being sure about the ability to perform tasks related career decision making is one factor that holds an important role on career adaptability. This sense of confidence is often called as career decision self-efficacy. The aim of this research was to identify which source of self-efficacy that plays a significant role to form career adaptability with career decision self-efficacy as a mediator. The study involved Year 12 grade students of senior high school, consisting of 47 male and 205 female. Career AdaptAbilities Scale (CAAS), Career Decision-Making Self-EfficacyShort Form (CDSE-SF), and Career Exploration and Decision Learning Experiences (CEDLE) Scale were used to collect the data. The results show that career decision self-efficacy (CSDE) mediated the relationship between each source of self efficacy to career adaptability. Four of five sources of self-efficacy provide influence through two ways, i.e. direct influence on career adaptability and through the mediating role of CDSE. Meanwhile, other people's successful experience has an influence on career adaptability only through CDSE mediation. Therefore, enhancing one or more source of self-efficacy will help adolescence develop a good career adaptability.
\end{abstract}

\section{Introduction}

Career adaptability is the readiness to face the tasks that must be faced in preparing and undergoing a job and tasks that may appear as a part of the process of adjusting to the changes that occur in the career world (Savickas, 1997). Furthermore, Savickas (2013) defines career adaptability as a psychosocial construct that describes the readiness of individuals in carrying out career development tasks and is used to overcome the currently undertaken developmental tasks - the transition from the school to the career world and the personal trauma that affects it. A person who has a good career adaptability is characterized by the ability to plan a chosen career, explore self and the environment, gather information about the chosen career field and be able to decide what career to follow (Savickas \& Porfeli, 2012). The existence of a problem from one dimension of career adaptability may cause problems in career development or selection (Savickas, 2013). 
Based on the results of a two-year study organized by Youthmanual on more than 400,000 profiles and data among high school students in Indonesia, 92\% of high school students and equal level faced problems in planning and career decision making (Yunandika, 2018). Students have difficulty in making career decisions because they do not understand the talent and potential they have to be matched to the type of existing work (Christian as cited in Bashkara, 2018). It was also found that as many as $45 \%$ of students in Indonesia felt they have taken the wrong major when they had started attending higher education (Yunandika, 2018). The data show that adolescents experience difficulties in developing career adaptability. The inability to develop the ability to explore oneself and the environment and gather information about this career field makes most adolescents finally feel uncertain about the choice of majors that must be taken during their higher education degree selection. Therefore adolescents will be faced with career indecisiveness conditions that later can have an impact on the inability to choose a career path or choose a career that is not in accordance with their own character (Fouad, Cotter, \& Kantamneni, 2009).

This condition can be overcome by helping adolescents grow self-efficacy in tasks related to career decision making (Amir \& Gati, 2006; Fouad et al., 2009). Career adaptability is influenced by proactive personality, which is mediated by self-efficacy in career decision making (CDSE)(Hou, Wu, \& Liu, 2014). The results show that individuals who have a high proactive personality (actively seeking information and planning before acting) will have high self-efficacy in completing career development tasks (Hou et al., 2014). Individuals with high CDSE will be able to assess their self-esteem and desired career path, so they later will be able to anticipate possible problems that may arise (Hirschi \& Valero, 2015).

Bandura (1982) in the framework of Social Learning Theory suggests that one's selfefficacy can be formed through four ways, i.e. successful experience, verbal persuasion, examples of the success of others, and physiological conditions. Successful experience refers to past experiences (especially successful experience) on similar tasks, while examples of other people's successes refer to the successful experience obtained by others (behavioral models) that are perceived to have similar characteristics and abilities (Bandura, 1997). Meanwhile, verbal persuasion refers to the feedback received by someone as a consequence of completing a task, and physiological conditions are responses or physical differences that occur when performing a task (Bandura, 1997). Klassen (2004) then classifies the four sources of formation of self-efficacy into two categories, i.e. sources originating from within themselves (successful experience and physiological conditions) and sources that come from outside the self (verbal persuasion and examples of success of others).

Ahn, Bong, \& Kim (2017) conduct research by adding the role of social support derived from three significant figures on adolescents' life as the source of self-efficacy formation. The three significant figures are teachers, family members, and peers. The three significant figures are figures who have important roles in the lives of adolescents (Santrock, 2014). Parents and siblings will express their hopes and provide information regarding education and employment choices (Sawitri, Creed, \& Zimmer-Gembeck, 2014). The teacher is a role model for students in school and a good relationship between teachers and students can improve self-efficacy (Lee, Lee, Song, \& Kim, 2015). Adolescents are willing to change the career path they will undergo to be the same as a friend's career path due to their unwillingness to be parted with their best friend or for fear of feeling alone in their educational choices later (Sinclair, Carlsson, \& Björklund, 2014). Ahn et al. (2017) found the successful experience and positive emotions are stable predictors in the formation 
of self-efficacy. Teacher's succesfull experience on solving mathematical questions play an important role in the formation of student self-efficacy. Meanwhile, verbal persuasion has a diverse influence on students both given by family members, teachers, and peers in doing Math and English assignments (Usher \& Pajares, 2009).

The mechanism for the formation of self-efficacy has been studied in the implementation of tasks related to self-efficacy in the academic field. The mechanism for the formation of self-efficacy on the task of career decision making is examined by Lent et al., (2017) with five significant dimensions of the source of CDSE formation. In the study, it was found that the dimensions of success experience were the strongest predictors in CDSE formation, followed by positive emotions, verbal persuasion, examples of other people's successes, and negative emotions successively as significant predictors.

Based on the association between the results of past researches on career adaptability, CDSE, and the source of self-efficacy, the researchers of this current study intend to combine the research that has been done by Hou et al. (2014) and Lent et al. (2017) among Indonesian students. This study aimed to determine the role of CDSE in mediating the role self-efficacy sources on career adaptability in high school students in Jakarta and Bekasi. The five sources of self-efficacy formation may have a significant influence on CDSE and CDSE has a significant influence on career adaptability. The results of this study are expected to be an additional literature in the field of career counseling and may help counseling teachers in helping students build self-efficacy in career decision-making that later build students' ability to adapt in career-related environments.

\section{Method}

Respondents were Year 12 high school students in Jakarta and Bekasi, as students at the Year 12 level of high school must decide what major they would choose in higher education after they finished their education in high school. At the time this research was conducted, students were facing the National Selection to Enter State Universities (SNMPTN).

Snowball sampling was used to select respondents, where the researchers only have criteria on respondents and include samples that are initially small in number, but become larger due to the researchers ask for the samples to distribute questionnaires to other samples known by respondents (Cozby \& Bates, 2015). The respondents filled online or printed questionnaires. The total respondents are 252 people (109 online questionnaire, 143 printed questionnaire).

Respondents aged ranging from 15 to 18 years old, with the average 17.02 years old. The majority of the respondents were female $(81.3 \%)$. Larger sample were majoring in natural science $(61.1 \%)$ compare to social science $(38.9 \%)$. Students with language major did not involve because of not every school have language class, moreover only small number of students choose language class.

Three scale were used to collect the data. First, the Career Adapt-Abilities Scale (CAAS) scale developed by Savickas \& Porfeli (2012). The CAAS has been adapted by Indianti (2015) for university student, and then modified by Jasmine (2016) for high school student. Some example of the items are "I have planned for the program I have chosen since junior high school", "I re-examined the answer to the exam before it was submitted", and "I am interested in trying new things". The CAAS consists of 24 items with interval scale response of 1 to 4 . Response 1 means the statement is not in accordance with the respondent, up to 4 which means the statement is in accordance with the respondent. The 
reliability value in our sample was .869. The validity test using Confirmatory Factor Analysis (CFA) shows the factor loading ranged from .21 to .53.

Second, the Career Decision-Making Self-Efficacy-Short Form (CDSE-SF) developed by Betz, Klein, \& Taylor (1996), that has been adapted into Bahasa Indonesia by Sawitri (2009). The CDSE-SF consists of 25 items that measure five dimensions of the CDSE. The five dimensions are self-assessment, information seeking, goal setting, future planning, and problem solving. Some example of items are "Using the internet to find information on the career that you think is interesting", "Choose a department for the continuation of studies from several departments that you have considered", and "Make a plan to achieve your goals for the next 5 years ". The response of each item ranges from 1 (not at all sure) to 6 (very sure). The validity test using CFA shows the factor loading between .29 and .89 . The reliability coefficient is .91 .

Third, the Career Exploration and Decision Learning Experiences (CEDLE) scale developed by Lent et al. (2017) to measure the source of self-efficacy in career decision making based on Bandura's self-efficacy theory in the task of career decision making. The CEDLE scale composed of five measurement dimensions. The five dimensions of the source of self-efficacy are the successful experience (e.g., "I can judge the positives and negatives from several different choices when having to make career decisions"), verbal persuasion (e.g., "... saying that I am able to gather information needed to make careerrelated decisions"), examples of the success of others (e.g., " ... exemplify how to gather information needed to make career-related decisions"), and physiological conditions that are divided into two emotional groups, i.e. positive emotions (e.g., "Excited") and negative emotions (e.g., "Fear"). The response on each item differs according to its dimensions. On the dimension of success experience, the responses ranged from 1 to 5. Meanwhile, on the dimensions of verbal persuasion, examples of the success of others, and positive emotions and negative emotions, the responses ranged from 1 to 6 . Table 1 shows the validity and reliability of the scale.

Table 1

Reliability and Validity of the CDSE Scale

\begin{tabular}{lccc}
\hline \multicolumn{1}{c}{ Dimensions } & Number of item & $\begin{array}{c}\text { Reliability } \\
\text { (Alpha Cronbach) }\end{array}$ & $\begin{array}{c}\text { Validity } \\
\text { (CFA) }\end{array}$ \\
\hline Successful experience & & .809 & $.52-.74$ \\
Verbal persuasion & 12 & .913 & $.69-.87$ \\
Examples of the success of others & 12 & .898 & $.66-.90$ \\
Positive emotion & 4 & .722 & $.21-.73$ \\
Negative emotion & 4 & .707 & $.48-.88$ \\
\hline
\end{tabular}

Data analysis was carried out with multiple regression, to see the effect of predictor variables on outcome variables (Cozby \& Bates, 2015). The researchers performed the research hypothesis test not only with linear multiple regression, but also by using a macro formula called PROCESS to test the role of mediation. This PROCESS formula is made by Hayes (2013). The researchers used model 4 for simple on PROCESS version 2.16 to obtain the test results of mediator influences in a simple form The testing using the PROCESS macro does not require a normality assumption test because the significance testing will be done using the bootstrap method (Hayes, 2013). Before testing the research hypothesis, The researchers need to change the total score obtained on each variable into a standard score because of the differences in the scale interval of each measuring instrument, so that the three measurement data are equivalent (Field, 2009). These standardized scores 
are then calculated using the macro formula and the significance value of the effect was tested.

\section{Results}

Prior to the hypothesis test, the researchers looked at the correlation of each variable using the Spearman correlation. The results of the correlation test between variables and descriptive description can be seen in Table 2 . 
Table 2

Correlation between Variables

\begin{tabular}{|c|c|c|c|c|c|c|c|c|c|c|c|c|c|c|}
\hline & Variable & Min & Max & Mean & SD & 1 & 2 & 3 & 4 & 5 & 6 & 7 & 8 & 9 \\
\hline 1 & Major & - & - & - & - & - & & & & & & & & \\
\hline 2 & Sex & - & - & - & - & ,068 & - & & & & & & & \\
\hline 3 & Successful experience & 1 & 5 & 3.91 & .703 &, 046 &, 005 & - & & & & & & \\
\hline 4 & Verbal persuasion & 1 & 6 & 4.632 & .838 & ,097 &, 067 &, $658 * *$ & - & & & & & \\
\hline 5 & Examples of the success of others & 1 & 6 & 4.606 & .879 & ,189 &, $175^{*}$ &, $617 * *$ &, $831 * *$ & - & & & & \\
\hline 6 & Positive Emotion & 1 & 6 & 4.254 & .687 & ,037 &, 044 &, $690 * *$ &, $652 * *$ &, $543 * *$ & - & & & \\
\hline 7 & Negative Emotion & 1 & 6 & 2.951 & .880 &, $158 *$ & $174 *$ &,$- 288 * *$ &,$- 212 * *$ &,- 093 &,$- 441 * *$ & - & & \\
\hline 8 & CDSE & 1 & 6 & 4.620 & .735 &, 027 &,- 089 &, $792 * *$ &, $736 * *$ &, $676 * *$ &, $711 * *$ &,$- 326 * *$ & - & \\
\hline 9 & Career Adaptability & 1 & 4 & 3.126 & .459 &,- 093 &,- 070 &, $665 * *$ &, $652 * *$ &, $508 * *$ &, $735 * *$ &,$- 471 * *$ &, $727 *$ & - \\
\hline
\end{tabular}


Mediation test is performed to see the influence of sources of self-efficacy on career adaptability through the mediating role of CDSE. The each source of self-efficacy was tested separately because of the large correlation of each variable (Table 2). The independent variable that has a greater influence will make the variable with smaller influence become insignificant (Hayes, 2013).

Table 3

Mediation Test of the Influence of Successful Experience

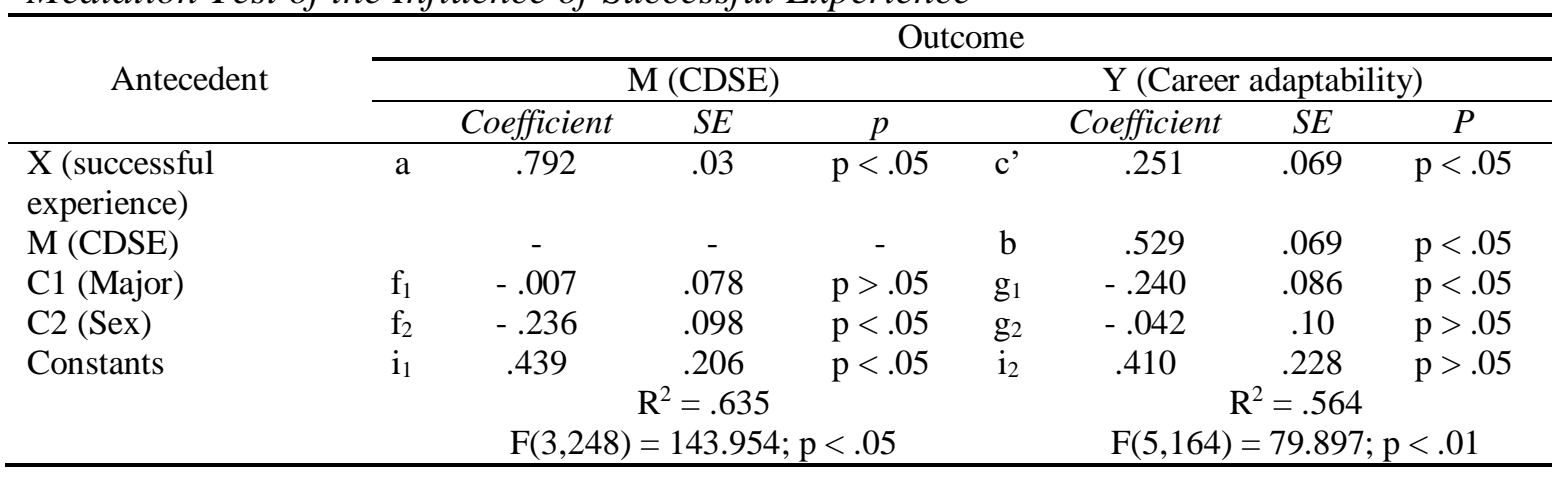

Simple mediation testing found that the successful experience affects the ability to adapt in the career world through self-efficacy in making career decisions. This can be seen in Table 3, that the successful experience influences the self-efficacy of respondents in making career decisions $(\mathrm{a}=.792)$ and respondents who have high efficacy in making career decisions will adapt to changes related to the career world $(b=.592)$ The results of this test are statistically significant value based on the testing using the bootstrap method. The confidence interval of testing indirect effects through the mediator $(a b=.419)$ based on the entire 10,000 bootstrapped samples is worth above zero (.309 to .532). Testing the direct effect of the successful experience on career adaptability without going through the CDSE also showed a significant value $\left(\mathrm{c}^{\prime}=.251 ; \mathrm{p}=.0004\right)$.

Table 4

Mediation Test of the Influence of Verbal Persuasion

\begin{tabular}{|c|c|c|c|c|c|c|c|c|}
\hline \multirow{3}{*}{ Antecedent } & \multicolumn{8}{|c|}{ Outcome } \\
\hline & & \multicolumn{3}{|c|}{$\mathrm{M}(\mathrm{CDSE})$} & \multicolumn{4}{|c|}{ Y (Career adaptability) } \\
\hline & & Coefficient & $S E$ & $p$ & & Coefficient & $S E$ & $p$ \\
\hline X (Verbal Persuasion) & $\mathrm{a}$ & .749 & .042 & $p<.05$ & $c^{\prime}$ & .287 & .063 & $\mathrm{p}<.05$ \\
\hline $\mathrm{M}(\mathrm{CDSE})$ & & - & - & - & $\mathrm{b}$ & .515 & .062 & $\mathrm{p}<.05$ \\
\hline C1 (Major) & $\mathrm{f}_{1}$ & -.074 & .086 & $\mathrm{p}>.05$ & $\mathrm{~g}_{1}$ & -.270 & .085 & $\mathrm{p}<.05$ \\
\hline C2 (Sex) & $\mathrm{f}_{2}$ & -.349 & .108 & $\mathrm{p}<.05$ & $\mathrm{~g}_{2}$ & -.089 & .108 & $\mathrm{p}>.05$ \\
\hline \multirow[t]{3}{*}{ Constants } & $\mathrm{i}_{1}$ & .736 & .227 & $\mathrm{p}<.05$ & $\mathrm{i}_{2}$ & .537 & .228 & $\mathrm{p}>.05$ \\
\hline & \multicolumn{4}{|c|}{$\mathrm{R}^{2}=.562$} & & \multicolumn{3}{|c|}{$\mathrm{R}^{2}=.577$} \\
\hline & \multicolumn{4}{|c|}{$\mathrm{F}(3,248)=106.432 ; \mathrm{p}<.05$} & & \multicolumn{3}{|c|}{$\mathrm{F}(4,247)=84.231 ; \mathrm{p}<.05$} \\
\hline
\end{tabular}

Verbal persuasion influences the ability to adapt in the career world through selfefficacy in making career decisions. This can be seen in Table 4, that the feedback on the successful experience given by the environment influences respondents' self-efficacy in making career decisions $(\mathrm{a}=.749)$ and respondents who have high efficacy in making career decisions will adapt to changes related to the career world $(b=.515)$. The results of this test have a statistically significant value based on the testing using the bootstrapped method. The confidence interval of the indirect effect test through the mediator $(a b=.386)$ based on the total 10,000 bootstrapped samples is worth above zero (.296 to .49). Testing 
the direct effect of verbal persuasion on career adaptability without going through the CDSE also showed a significant value $\left(\mathrm{c}^{\prime}=.287 ; \mathrm{p}=.0000\right)$.

Table 5

Mediation Test of the Influence of Examples of the Others' Successful Experience

\begin{tabular}{|c|c|c|c|c|c|c|c|c|}
\hline \multirow{3}{*}{ Antecedent } & \multicolumn{8}{|c|}{ Outcome } \\
\hline & & \multicolumn{3}{|c|}{$\mathrm{M}(\mathrm{CDSE})$} & & \multicolumn{3}{|c|}{ Y (Career adaptability) } \\
\hline & & Coefficient & $S E$ & $P$ & & Coefficient & $S E$ & $P$ \\
\hline $\begin{array}{l}\mathrm{X} \text { (Examples of others } \\
\text { successful experience) }\end{array}$ & $\mathrm{a}$ & .731 & .045 & $\mathrm{p}<.05$ & $\mathrm{c}^{\prime}$ & .075 & .063 & $p>.05$ \\
\hline $\mathrm{M}(\mathrm{CDSE})$ & & - & - & - & b & 677 & .061 & $\mathrm{p}<.05$ \\
\hline C1 (Major) & $\mathrm{f}_{1}$ & -.198 & .092 & $\mathrm{p}<.05$ & $\mathrm{~g}_{1}$ & -.254 & .090 & $\mathrm{p}<.05$ \\
\hline C2 (Sex) & $\mathrm{f}_{2}$ & -.538 & .115 & $p<.05$ & $\mathrm{~g}_{2}$ & -.038 & .116 & $p>.05$ \\
\hline \multirow[t]{3}{*}{ Constants } & $i_{1}$ & 1.253 & .246 & $\mathrm{p}<.05$ & $\mathrm{i}_{2}$ & .423 & .250 & $\mathrm{p}>.05$ \\
\hline & \multicolumn{5}{|c|}{$\begin{array}{c}\mathrm{R}^{2}=.510 \\
\end{array}$} & \multirow{2}{*}{\multicolumn{3}{|c|}{$\begin{array}{c}\mathrm{R}^{2}=.564 \\
\mathrm{~F}(5,164)=73.543 ; \mathrm{p}<.05\end{array}$}} \\
\hline & & $\mathrm{F}(3,248$ & $=86.16$ & $<.05$ & & & & \\
\hline
\end{tabular}

Examples of other people's success have an influence on the ability to adapt in the career world through self-efficacy in making career decisions. This can be seen based on Table 5, that the successful experience in making career decisions experienced by significant figures influences the self-efficacy of respondents in making career decisions (a $=.731$ ) and respondents who have high efficacy in making career decisions will adapt to changes relating to the career world $(b=.677)$. The results of this test have a statistically significant value based on the testing using the bootstrapped method. The confidence interval from testing indirect effects through the mediator $(\mathrm{ab}=.495)$ based on the total 10,000 bootstrapped samples is worth above zero (.4 to .615). The direct effect of the examples of others successful experience on career adaptability without going through CDSE shows a non-significant value ( $\left.c^{\prime}=.075 ; \mathrm{p}=.2307\right)$.

Table 6

Mediation Test of the Influence of Positive Emotion

\begin{tabular}{|c|c|c|c|c|c|c|c|c|}
\hline \multirow{3}{*}{ Antecedent } & \multicolumn{8}{|c|}{ Outcome } \\
\hline & & \multicolumn{3}{|c|}{ M (CDSE) } & \multicolumn{4}{|c|}{ Y (Career adaptability) } \\
\hline & & Coefficient & $S E$ & $p$ & & Coefficient & $S E$ & $P$ \\
\hline $\mathrm{X}$ (Positive emotion) & $\mathrm{a}$ & .716 & .044 & $p<.05$ & $c^{\prime}$ & .455 & .055 & $\mathrm{p}<.05$ \\
\hline $\mathrm{M}(\mathrm{CDSE})$ & & - & - & - & $\mathrm{b}$ & .402 & .055 & $\mathrm{p}<.05$ \\
\hline C1 (Major) & $\mathrm{f}_{1}$ & .017 & .090 & $\mathrm{p}>.05$ & $\mathrm{~g}_{1}$ & -.239 & .078 & $\mathrm{p}<.05$ \\
\hline C2 (Sex) & $\mathrm{f}_{2}$ & -.309 & .113 & $\mathrm{p}<.05$ & $\mathrm{~g}_{2}$ & -.119 & .099 & $\mathrm{p}>.05$ \\
\hline Constants & $\mathrm{i}_{1}$ & .536 & .237 & $\mathrm{p}<.05$ & $\mathrm{i}_{2}$ & .549 & .207 & $\mathrm{p}<.05$ \\
\hline & & & $=.520$ & & & & $=.64$ & \\
\hline
\end{tabular}

Positive emotional condition has an influence on the ability to adapt in the career world through self-efficacy in making career decisions. This can be seen in Table 6 , that the positive emotions felt when carrying out career decision making tasks has an influence on the self-efficacy of respondents in making career decisions $(\mathrm{a}=.716)$ and respondents who have high efficacy in making career decisions will adapt to related changes with the career world $(\mathrm{b}=.402)$. The results of this test have a statistically significant value based on the testing using the bootstrapped method. The confidence interval from testing indirect effects through the mediator $(\mathrm{ab}=.287)$ based on the total 10,000 bootstrapped samples is worth above zero (.199 to .385). Testing the direct effect of positive emotional conditions on 
career adaptability without going through CDSE showed a significant value $\left(\mathrm{c}{ }^{\prime}=.455 ; \mathrm{p}=\right.$ $.0000)$.

Table 7

Mediation Test of the Influence of Negative Emotion

\begin{tabular}{|c|c|c|c|c|c|c|c|c|}
\hline \multirow{3}{*}{ Antecedent } & \multicolumn{8}{|c|}{ Outcome } \\
\hline & & \multicolumn{3}{|c|}{$\mathrm{M}(\mathrm{CDSE})$} & \multicolumn{4}{|c|}{ Y (Career adaptability) } \\
\hline & & Coefficient & $S E$ & $p$ & & Coefficient & $S E$ & $p$ \\
\hline X (Negative emotion) & $\mathrm{a}$ & -.332 & .061 & $\mathrm{p}<.05$ & $c^{\prime}$ & -.254 & .439 & $\mathrm{p}<.05$ \\
\hline $\mathrm{M}(\mathrm{CDSE})$ & & - & - & - & $\mathrm{b}$ & .649 & .430 & $\mathrm{p}<.05$ \\
\hline C1 (Sex) & $\mathrm{f}_{1}$ & .167 & .124 & $\mathrm{p}>.05$ & $\mathrm{~g}_{1}$ & -.148 & .084 & $\mathrm{p}>.05$ \\
\hline C2 (Sex) & $f_{2}$ & -.094 & .155 & $\mathrm{p}>.05$ & $\mathrm{~g}_{2}$ & .093 & .105 & $\mathrm{p}>.05$ \\
\hline \multirow[t]{3}{*}{ Constants } & $\mathrm{i}_{1}$ & -.061 & .329 & $p>.05$ & $\mathrm{i}_{2}$ & .037 & .223 & $\mathrm{p}>.05$ \\
\hline & \multicolumn{5}{|c|}{$\mathrm{R}^{2}=.113$} & \multicolumn{3}{|c|}{$\mathrm{R}^{2}=.595$} \\
\hline & \multicolumn{5}{|c|}{$\mathrm{F}(3,248)=10.608 ; \mathrm{p}<.05$} & \multicolumn{3}{|c|}{$\mathrm{F}(4,247)=91.050 ; \mathrm{p}<.05$} \\
\hline
\end{tabular}

Negative emotional conditions affect the ability to adapt in the career world through self-efficacy in making career decisions. This can be seen in Table 7, that the negative emotions felt when carrying out career decision making tasks has an influence on the selfefficacy of respondents in making career decisions $(\mathrm{a}=-.332)$ and respondents who have efficacy in making high career decisions will adapt to changes relating to the career world $(b=.649)$. The result of this test has a statistically significant value based on testing using the bootstrapped method. The confidence interval from testing indirect effects through the mediator $(\mathrm{ab}=-.215)$ based on all 10,000 bootstrapped samples is worth below zero (-308 to -.129). Testing the direct effect of negative emotional conditions on career adaptability without going through CDSE shows a significant value $\left(c^{\prime}=-.254 ; \mathrm{p}=.0000\right)$.

The results of the CDSE mediation test on the influence of the five sources of selfefficacy on career adaptability can be seen in Table 8 .

Table 8

Summary of Mediation Test

\begin{tabular}{lcc}
\hline \multicolumn{1}{c}{ Predictor variable } & Direct effect $\left(c^{\prime}\right)$ & Indirect effect $(a b)$ \\
\hline Experience of success & $.251^{*}$ & $.419^{*}$ \\
Verbal persuasion & $.287^{*}$ & $.318^{*}$ \\
Examples of other successful experience & .075 & $.495^{*}$ \\
Positive emotion & $.455^{*}$ & $.287^{*}$ \\
Negative emotion & $-.254^{*}$ & $-.215^{*}$ \\
\hline$* \mathrm{p}<.05$ & &
\end{tabular}

The biggest mediating role of CDSE appear on the influence of examples of other successful experience in career decision making on career adaptability. This means that the examples of success from significant figures such as family members, friends, or teachers help individuals form self-efficacy in making career decisions. Individuals who have efficacy in making career decisions will shape their ability to adapt to changes that occur in themselves and the environment related to the career world. Meanwhile, the smallest mediating role is the influence of negative emotions on career decision making. However, this mediating role remains on significant value. 


\section{Discussion}

The results of this study indicate that each dimension of the sources of self-efficacy has a significant influence on career adaptability through the mediating role of CDSE. This is in accordance with the findings of Lent et al. (2017) which shows that the successful experience, verbal persuasion, examples of other's successful experience, positive emotions, and negative emotions are the most stable predictors in shaping self-efficacy. In this study it was found that the successful experience, positive feedback after successfully carrying out assignments, examples of successful experience of significant figures, and positive emotions when carrying out career decision making tasks increase the belief in an individual's success in their ability to complete career decision making tasks. Meanwhile, the negative emotional conditions when making career decisions can reduce a person's confidence in their ability to make career decision making. The confidence that a person will succeed in making career decisions helps the person to be more adaptable to changes in themselves and in the career related environment. The findings in this study are consistent with the findings of the studies of Hou et al. (2014) and Lee et al. (2015).

The role of other's successful experience in this study is the strongest predictor compared to other predictor variables. This result is in line with the research conducted by Usher \& Pajares (2009), that the example of the success of a significant figure serves as one of the predictors of the formation of self-efficacy. Adolescents have a tendency to mimic the performance of peers who successfully perform tasks similar to those that will be undertaken (Usher \& Pajares, 2009). Lee et al. (2015) found that family, teachers, and friends had a significant influence on the selection of secondary school students in South Korea through the role of self-efficacy mediation. In addition, successes that are exemplified or told by teachers at school or by parents at home also have a significant role in the formation of self-efficacy (Ahn et al., 2017). The story of the successful experience from this significant figure provides information to someone on what must be done to achieve the same success, so later it will shape adolescents' self-confidence when they are going to decide what career they wish to pursue (Lent et al., 2017).

When someone has succeeded in previous career decision making, then in the future the person will feel more confident in carrying out the same task (Lent et al., 2017). If the individual has experienced previous positive experience, then the person will feel competent and able to show good performance in a task that has the same type as previous assignments. Decision making related to career that has been done by high school students such as choosing a high school that is now being undertaken or choosing a department (nature or social science) when going up from Year 9 (graduating from junior high school) to Year 10 (entering senior high school). However, in this study the experience factors of success were not the most powerful predictors in predicting CDSEs, in contrast to the study of Lent et al. (2017). This difference may occur because the influence of parents in choosing children's career paths plays a big role in collectivist culture like in Indonesia (Sawitri et al., 2014).

The CDSE also mediates the influence of verbal persuasion and emotional conditions (both positive and negative) on career adaptability. This is similar to the findings in the study of Lent et al. (2017), which state that verbal persuasion and emotional conditions were significant predictors in CDSE formation. The feedback provided by significant figures such as parents, teachers, and friends after successfully completing a task can help a person build their efficacy (Ahn et al., 2017). Families play a role in shaping the CDSE in adolescents by helping young people to assess themselves (helping to develop interest in certain occupations), helping to set goals and giving advice in making decisions, making 
plans about the future, and helping find solutions and alternative solutions to problems found in making career decisions (Guan et al., 2016). This is in line with Sawitri et al. (2014) that parents' expectations of careers that will be chosen by children has an influence on the exploration behavior of their careers and form self-efficacy in making choices and in planning their careers later. This feedback is used as input to conduct an assessment of one's abilities to strengthen confidence in carrying out similar tasks in the future (Lent et al., 2017).

In addition to input given by the social environment, positive emotions such as "enthusiasm" can lead someone to be more triggered in exploring and searching for desired career-related information (Lent et al., 2017). Someone who explores the desired career field and seeks as much information as possible before making a decision will feel more confident in making their career decision later (Ochs \& Roessler, 2004). Readiness and confidence in making these decisions will then help someone to adapt to all forms of career demands that will be faced later in the career world (Hou et al., 2014).

Verbal persuasion and emotional conditions can directly influence the adaptability of a person's career. This can be seen in the research conducted by Sinclair et al. (2014) to see the influence of the need to stay together with peers on career choices from adolescents in Sweden. The findings of the first study show that a person's fear of separation from their best friend is one of the factors that makes adolescents adjust the choice of high school majors. The students choose to be the in same high school as their best friend even though the student initially is not interested in that choice. In the second study, Sinclair et al., (2014) found that the mediation of feelings of being isolated if separated from peers made adolescents change their education majors to resemble their friends' choices. The feedback given by a significant figure and the negative emotions felt after making a career decision can make a person change his decision (Lent et al., 2017).

The respondents in this study were focused on the Year 12 high school students with an average age of 17 years old. Therefore, the suggestion that the researchers propose for the next study is to add the scope of research respondents including Year 10 and Year 11 students of high school to see an overview of the influence of CDSE sources on career adaptability in adolescents. In addition, in this study the included respondents only came from high school education level. Generally, in Indonesia there are three types of education for the high school level, i.e. SMA (High School), SMK (Vocational High School), and MA (Islamic based High School). These three types of education have different characteristics from one another in terms of directing students to plan their career paths in the future. High school education level directs students in the academic field in general, MA or Islamic High Schools direct the field of religious studies, while Vocational Schools direct students to field work practices. The difference in information exposure during the course of this education made the researchers suggest that additional respondents from vocational and MA education be made as a variation of the types of education for the future studies.

The formation of career adaptability and CDSE is a process in which each predictor influencing that may have different effects at certain times. Friends can be a source of obtaining key information about the desired career path at the beginning of the study period of students in high school, but all information that has been obtained will be validated based on input and feedback provided by parents and teachers. Therefore, using a combination of quantitative approaches with qualitative analysis will provide both general picture of the dynamics between sources of self-efficacy, CDSE and career adaptability, and an in-depth picture of the formation process of CDSE and career adaptability. By combining the results of quantitative analysis with the results of qualitative analysis, therefore, the description of 
career adaptability, CDSE, and the influence of each predictor that the previous researchers described can be seen more clearly.

\section{Conclusion}

The five sources of self-efficacy formation have a significant influence on career adaptability through mediation of career decision self-efficacy. Successful experience, verbal persuasion, positive and negative emotional conditions, and examples of other people's success shape an individual's beliefs in making career decisions and the individuals who feel confident that they can make the right career decisions for themselves will have the ability to adapt to the changes that occur in oneself and the career related environment. The four sources of self-efficacy, i.e. the successful experience, verbal persuasion, positive and negative emotional conditions provide influence through two ways, i.e. direct influence on career adaptability and through the mediating role of CDSE. Meanwhile, other people's successful experience has an influence on career adaptability only through CDSE mediation.

\section{References}

Ahn, H. S., Bong, M., \& Kim, S. (2017). Social models in the cognitive appraisal of selfefficacy information. Contemporary Educational Psychology, 48, 149-166. https://doi.org/10.1016/j.cedpsych.2016.08.002

Amir, T., \& Gati, I. (2006). Facets of career decision-making difficulties. British Journal of Guidance \& Counselling, 34(4), 483-503. https://doi.org/10.1080/03069880600942608

Bandura, A. S. (1982). Self-efficacy mechanism in human agency. American Psychologist, 37(2), 122-147. https://doi.org/10.1037/0003-066X.37.2.122

Bandura, A. S. (1997). Self-efficacy: The exercise of control. New York, NY: W H Freeman Company.

Bashkara, P. (2018, January 25). Banyak lulusan SMA yang sadar salah jurusan ketika sudah jadi mahasiswa (Many high school graduates are aware of the wrong direction when they are undergraduate students). Warta Kota. Retrieved from http://wartakota.tribunnews.com/2018/01/25/banyak-lulusan-sma-yang-sadar-salahjurusan-ketika-sudah-jadi-mahasiswa

Betz, N. E., Klein, K. L., \& Taylor, K. M. (1996). Evaluation of a short form of the career decision-making self-efficacy scale. Journal of Career Assessment, 4(1), 47-57. https://doi.org/10.1177/106907279600400103

Cozby, P. C., \& Bates, S. (2015). Methods in behavioral research (Twelfth ed). New York, NY: McGraw-Hill Education.

Field, A. P. (2009). Discovering statistics using SPSS: and sex, drugs and rock " $n$ " roll (3rd ed). Los Angeles: SAGE Publications.

Fouad, N., Cotter, E. W., \& Kantamneni, N. (2009). The effectiveness of a career decisionmaking course. Journal of Career Assessment, 17(3), 338-347. https://doi.org/10.1177/1069072708330678

Guan, P., Capezio, A., Restubog, S. L. D., Read, S., Lajom, J. A. L., \& Li, M. (2016). The role of traditionality in the relationships among parental support, career decision- 
making self-efficacy and career adaptability. Journal of Vocational Behavior, 94, 114-123. https://doi.org/10.1016/j.jvb.2016.02.018

Hayes, A. F. (2013). Introduction to mediation, moderation, and conditional process analysis. New York, NY: Guilford Press.

Hirschi, A., \& Valero, D. (2015). Career adaptability profiles and their relationship to adaptivity and adapting. Journal of Vocational Behavior, 88, 220-229. https://doi.org/10.1016/j.jvb.2015.03.010

Hou, C., Wu, L., \& Liu, Z. (2014). Effect of proactive personality and decision-making self-efficacy on career adaptability among Chinese graduates. Social Behavior and Personality: An International Journal, 42(6), 903-912. https://doi.org/10.2224/sbp.2014.42.6.903

Indianti, W. (2015). Dukungan sosial dan regulasi diri dalam belajar untuk membangun adaptabilitas karier pada mahasiswa baru Universitas Indonesia (Social support and self regulation in learning to develop carier adaptability among ner undergraduate students in University of (Ph.D Thesis). Universitas Indonesia, Depok.

Jasmine, J. (2016). Hubungan antara persepsi siswa terhadap program bimbingan konseling karier dan adaptabilitas karir pada siswa SMA kelas 3 (The relationship between students' perception on carier counseling program and carier adaptability among Grade 3 students of senior (Undergraduate Thesis). Universitas Indonesia, Depok.

Klassen, R. M. (2004). A cross-cultural investigation of the efficacy beliefs of South Asian immigrant and Anglo Canadian nonimmigrant early adolescents. Journal of Educational Psychology, 96(4), 731-742. https://doi.org/10.1037/00220663.96.4.731

Lee, S.-A., Lee, H.-S., Song, H.-S., \& Kim, S.-G. (2015). The relationship between attachment and career maturity: The mediating role of self-efficacy. International Social Work, 58(1), 153-164. https://doi.org/10.1177/0020872812456053

Lent, R. W., Ireland, G. W., Penn, L. T., Morris, T. R., \& Sappington, R. (2017). Sources of self-efficacy and outcome expectations for career exploration and decisionmaking: A test of the social cognitive model of career self-management. Journal of Vocational Behavior, 99, 107-117. https://doi.org/10.1016/j.jvb.2017.01.002

Ochs, L. A., \& Roessler, R. T. (2004). Predictors of career exploration intentions: A social cognitive career theory perspective. Rehabilitation Counseling Bulletin, 47(4), 224233. https://doi.org/10.1177/00343552040470040401

Santrock, J. W. (2014). Adolescence (Fifteenth). New York, NY: McGraw-Hill Education.

Savickas, M. L. (1997). Career adaptability: An integrative construct for life-span, lifespace theory. The Career Development Quarterly, 45(3), 247-259. https://doi.org/10.1002/j.2161-0045.1997.tb00469.x

Savickas, M. L. (2013). Career construction theory and practice. Career Development and Counseling: Putting Theory and Research to Work, 2, 144-180.

Savickas, M. L., \& Porfeli, E. J. (2012). Career Adapt-Abilities Scale: Construction, reliability, and measurement equivalence across 13 countries. Journal of Vocational Behavior, 80(3), 661-673. https://doi.org/10.1016/j.jvb.2012.01.011

Sawitri, D. R. (2009). Pengaruh status identitas dan efikasi diri keputusan karir terhadap keraguan mengambil keputusan karir pada mahasiswa tahun pertama di Universitas Diponegoro (The effect of dentity status and carier decision self efficacy on doubts about making carier dec. Jurnal Psikologi Undip, 5(2), 14.

Sawitri, D. R., Creed, P. A., \& Zimmer-Gembeck, M. J. (2014). Parental influences and adolescent career behaviours in a collectivist cultural setting. International Journal 
for Educational and Vocational Guidance, 14(2), 161-180. https://doi.org/10.1007/s10775-013-9247-x

Sinclair, S., Carlsson, R., \& Björklund, F. (2014). The role of friends in career compromise: Same-gender friendship intensifies gender differences in educational choice. Journal of Vocational Behavior, 84(2), 109-118. https://doi.org/10.1016/j.jvb.2013.12.007

Usher, E. L., \& Pajares, F. (2009). Sources of self-efficacy in mathematics: A validation study. Contemporary Educational Psychology, 34(1), 89-101. https://doi.org/10.1016/j.cedpsych.2008.09.002

Yunandika, N. (2018, April 11). Angka siswa yang salah pilih jurusan masih tinggi (High number of students incorrectly choose department). Kompasiana.com. Retrieved from https://www.kompasiana.com/nikeputrie/5acdb6f1bde5752eb04d6ef2/angkasiswa-yang-salah-pilih-jurusan-masih-tinggi 